\title{
A Sensitivity Analysis for Thermal Performance of Building Envelope Design Parameters
}

\author{
Sara Elhadad $1,2,3, *(\mathbb{D})$ and Zoltan Orban ${ }^{4}(\mathbb{D}$ \\ 1 Department of Architecture, Faculty of Engineering, Minia University, Minia 61111, Egypt \\ 2 Szentágothai Research Centre, Energia Design Building Technology Research Group, Ifjúság útja 20, \\ H-7624 Pecs, Hungary \\ 3 Faculty of Engineering and Information Technology, Marcel Breuer Doctoral School, University of Pécs, \\ Boszorkány ut 2, H-7624 Pecs, Hungary \\ 4 Structural Diagnostics and Analysis Research Group, Faculty of Engineering and Information Technology, \\ University of Pécs, Boszorkány ut 2, H-7624 Pecs, Hungary; orban.zoltan@mik.pte.hu \\ * Correspondence: sarareda@mu.edu.eg; Tel.: +36-705-590-080
}

Citation: Elhadad, S.; Orban, Z. A Sensitivity Analysis for Thermal Performance of Building Envelope Design Parameters. Sustainability 2021, 13, 14018. https://doi.org/ $10.3390 /$ su132414018

Academic Editors: Nelson Soares and Luisa Dias Pereira

Received: 14 November 2021 Accepted: 16 December 2021 Published: 19 December 2021

Publisher's Note: MDPI stays neutral with regard to jurisdictional claims in published maps and institutional affiliations.

Copyright: (c) 2021 by the authors. Licensee MDPI, Basel, Switzerland. This article is an open access article distributed under the terms and conditions of the Creative Commons Attribution (CC BY) license (https:// creativecommons.org/licenses/by/ $4.0 /)$.

\begin{abstract}
Sensitivity analysis is crucial in building energy assessments. It is used to determine the major variables influencing building thermal performance, using both observational research and energy simulation models. This study investigates the most influential envelope design parameters on the thermal performance of a typical residential building in Budapest, Hungary. Sensitivity analysis is used in conjunction with the IDA-Indoor and Climate Energy (IDA-ICE 4.8) simulation tool to assess the effects of 33 envelope design parameters for energy consumption and carbon dioxide concentrations. The input parameters include thickness, materials, density, specific heat and thermal conductivity of the basement, exterior floor, interior floor, exterior wall, interior wall, roof, ground slab, glazing type, and infiltration rate. The results show that exterior floor materials have the biggest impact on annual delivered energy for heating and cooling, whereas the density of all structural elements and thickness of the basement, exterior floors, interior floors, and walls have minimal effects on energy consumption. It is also shown that the impact of all investigated parameters is not sensitive to the carbon dioxide concentration in the building. The authors consider that the findings of the paper assist designers to assess the performance of existing buildings and more efficiently generating alternative solutions in the energetic retrofitting of existing and energy design of new residential buildings.
\end{abstract}

Keywords: sensitivity analysis; thermal performance; buildings; IDA-ICE; design parameters

\section{Introduction}

In building science, designers and researchers frequently use dynamic thermal simulation software to analyze the energy and thermal performance of buildings to achieve specific goals, such as lower energy consumption, improved indoor thermal comfort, or reduced environmental effects [1-3]. As a result, several techniques for supporting building simulation analysis have been developed, such as simulation-based optimization, parametric simulations, sensitivity analysis, meta-model analysis, etc. Numerical simulations are frequently used to assess the energy performance of buildings. Despite many recent advancements in software to simulate building energy requirements, the discrepancy between predicted and actual energy consumption remains a constant issue. One reason behind this disparity in existing buildings may be due to uncertainties in the thermal and physical properties of building materials [4]. The properties vary as a result of (i) degradation over time, (ii) exposure to weather conditions, and (iii) traditional construction processes. Consequently, estimating actual material properties tends to improve the reliability and accuracy of building simulation software. Environmental and energy issues of buildings have recently received significant attention [5,6]. In addition to the development of green 
buildings, a large number of existing buildings must also be upgraded to an improved thermal performance level. The primary methods for improving the indoor environment in naturally ventilated residential buildings are envelope and ventilation design. As a result, optimal envelope retrofitting of existing buildings and envelope designs for new residential buildings are urgently required. The effects that design parameters of building envelopes have on energy performance and thermal comfort have been extensively researched. Increasing the insulation thickness can directly enhance the thermal properties of buildings, lowering cooling and heating energy consumption.

The optimal insulation thickness was investigated by Al-Khawaja, Alsayed, and Huang et al. [7-9]. The window-to-wall ratio (WWR) and building shape coefficient (building exterior area/building volume) are critical factors in the design of energy-efficient buildings [10,11]. The lower these factors are, the less heat is lost through the envelope and the less energy is consumed. The preceding study focuses primarily on residential and public buildings. As a result, the most important envelope design parameters differ from those of buildings with active cooling and heating. Uncertainty and sensitivity analysis is an effective tool to identify uncertainties in a system's or simulation tool's input and output [12-14]. The importance of sensitivity analysis in building energy analysis cannot be overstated. Sensitivity analysis is the study of the effects of changes in parameters of a mathematical model or system on the outputs or performance of the system. In other words, sensitivity analysis may be used to assign changes in a system's outputs to various sources of uncertainty in its inputs. Sensitivity analysis identifies the most important design parameters in terms of building performance. In practice, uncertainty and sensitivity analysis provide a number of additional advantages, including: (1) the use of parameter screening to simplify models $[15,16]$; (2) the evaluation of models' robustness [17]; (3) alerting designers to unexpected sensitivities that may result in errors, and/or incorrect specifications (quality assurance) [18-22]; and (4) providing a "what-if analysis" by changing the input parameters and displaying the effect on the outcome of a model (decision-support) [23].

By focusing on the most influential parameters, the number of parameters to be estimated using in situ measurements can be reduced. Furthermore, it significantly reduces the computational requirements of inverse problems [24]. The objective function was set to help with previously unmeasured existing buildings, especially with the historical or pronounced architectural value. As a result, sensitivity analysis has been widely used to investigate building thermal performance characteristics in a variety of applications, including building design $[25,26]$, energy model calibration $[27,28]$, building stock $[29,30]$, building retrofit and refurbishment [31,32], and the effect of climate change on thermal performance buildings [33,34]. Furthermore, practitioners of building energy modeling have shown a rising interest in uncertainty and sensitivity analysis approaches in recent years. From the perspective of a building energy retrofit, uncertainty analysis and sensitivity analysis are often used to evaluate the risk of various energy-saving methods and to aid decision-making.

Goffart et al. [35] applied the uncertainty analysis to evaluate the effects of bricks on the energy cooling demand of a structure. Yu et al. [36] conducted an energy performance sensitivity analysis to evaluate the effects of eight design parameters and defined the most important parameters for various WWR. Eisenhower et al. [37] proposed a sensitivity indices decomposition to identify which intermediate processes (e.g., heating sources, cooling sources air handling unit, etc.) made a significant contribution to the uncertainty of building simulation outputs. Spitz et al. [38] utilized 6669 simulation runs of the variance based Sobol method to find the most significant factors for an experimental home in France. The design variables that have the largest effect on a typical office building's energy performance are determined in [39]. Hopfe and Hensen [26] conducted sensitivity and uncertainty analysis on three types of office building input parameters: design parameters, physical parameters, and scenario parameters. Heiselberg et al. [40] applied a local sensitivity method, the Morris method [41], to perform sensitivity analysis 
on office buildings in Denmark to assess the impact of design parameters on total building energy demand. Heo et al. [42] used the Morris design technique to describe the ranking of energy usage intensity for office buildings in Chicago's commercial center. Tian and Choudhary [31] utilized the standardized regression coefficient (SRC) technique to identify the major parameters influencing energy use in London school buildings. Song et al. [43] used a treed-based Bayesian Gaussian model (one of the meta-modeling sensitivity analysis approaches) to analyze the energy usage trends of a London office building.

This paper identifies the most important envelope design parameters for buildings in general, but a two-storied residential building located in Budapest (Hungary) was used as a case study to demonstrate the use of the proposed methodology in practice sensitivity analysis of 33 envelope design parameters for energy consumption and carbon concentrations was performed. The input parameters included the thickness, materials, density, specific heat, and thermal conductivity of the basement, exterior floor, interior floor, exterior wall, interior wall, roof, and ground slab, glazing type, and infiltration rate. It is assumed that the findings of the paper assist designers to assess the performance of existing buildings and more efficiently generate alternative solutions in the energetic retrofitting of existing and energy design of new buildings.

\section{Materials and Methods}

\subsection{Case Study}

For the purpose of the sensitivity analysis, family building is proposed, representing a typical residential building type in the world's largest building sector. This reference building is a two-story floor located building in Budapest, Hungary (Figure 1). The ground floor area consists of 14 zones with a total area of $200 \mathrm{~m}^{2}$ with a ceiling height of $2.8 \mathrm{~m}$, 4 zones are distributed on the first floor the first-floor area is $187 \mathrm{~m}^{2}$ with a ceiling height of $2.6 \mathrm{~m}$.
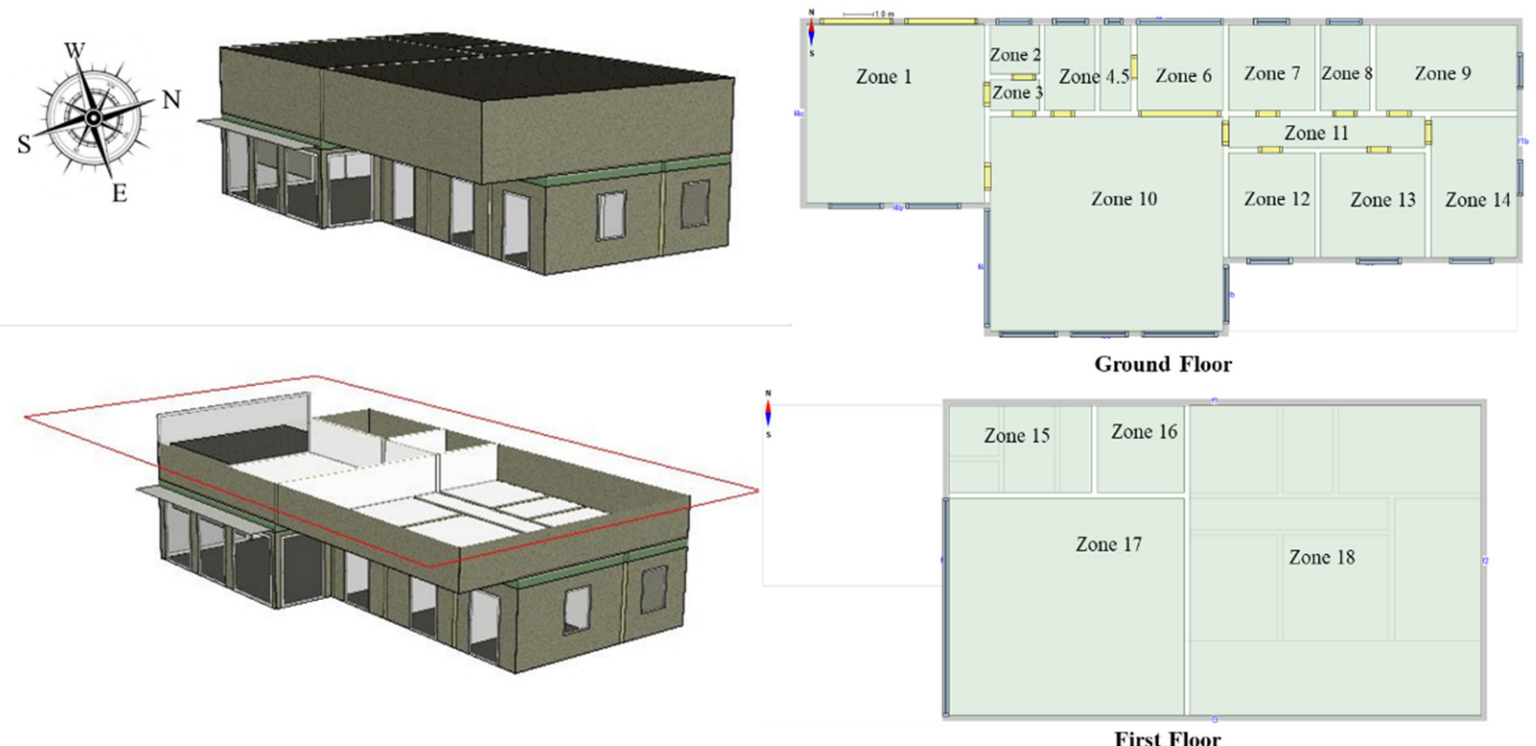

Figure 1. IDA-ICE model of the case study.

IDA-ICE was utilized as a reliable tool to simulate the building's energy and thermal comfort performance providing a comprehensive model and sensitivity analysis [44]. Table 1; Table 2 summarize the used materials in the construction of this building and input data. The schedules for occupants and lighting were created based on the assumption of regular daily patterns. Occupancy and lighting schedules on weekdays and weekend for different thermal zones are defined in IDA-ICE as shown in Figure 2. The properties of thermal zones in the investigated building are presented in Table A1. The internal emitted heat per person was assumed to be $75 \mathrm{~W}$ when present. Constant clothing level was set 
$0.85 \pm 0.25$ CLO (clothing is automatically adapted between limits to obtain comfort). Ventilation air change rate and air pressure difference are set by $0.5 \mathrm{ACH}$ and $50 \mathrm{~Pa}$, respectively. No integrated window shading was used in this building.

Table 1. The used materials in the construction of the investigated building (reference).

\begin{tabular}{|c|c|c|c|c|c|c|}
\hline Component & Material & $\begin{array}{c}\text { Thickness } \\
\text { (m) }\end{array}$ & $\begin{array}{l}\text { Conductivity } \\
\text { (W/m K) }\end{array}$ & $\begin{array}{l}\text { Density } \\
\left(\mathrm{kg} / \mathrm{m}^{3}\right)\end{array}$ & $\begin{array}{c}\text { Specific } \\
\text { Heat } \\
(\mathrm{J} /(\mathrm{kg} \mathrm{K}))\end{array}$ & U-Value \\
\hline \multirow{5}{*}{$\begin{array}{l}\text { Exterior } \\
\text { Wall }\end{array}$} & Gypsum & $5.0 \mathrm{E}-4$ & 0.29 & 800 & 840 & \multirow{4}{*}{0.4518} \\
\hline & Plasterboards & 0.02 & 0.24 & 1000 & 840 & \\
\hline & Air gap & 0.05 & 0.17 & 1.2 & 1006 & \\
\hline & Brick & 0.11 & 0.58 & 1500 & 840 & \\
\hline & $\begin{array}{l}\text { Baumit } \\
\text { noble } \\
\text { plaster }\end{array}$ & 0.002 & 0.93 & 1500 & 880 & \\
\hline \multirow{3}{*}{$\begin{array}{l}\text { Interior } \\
\text { Wall }\end{array}$} & Plasterboard & 0.015 & 0.24 & 1000 & 840 & \multirow{3}{*}{1.752} \\
\hline & Brick & 0.16 & 0.58 & 1500 & 840 & \\
\hline & Plasterboard & 0.19 & 0.24 & 1000 & 840 & \\
\hline Door & Wood & 0.05 & 0.14 & 500 & 2300 & 1.897 \\
\hline \multirow{4}{*}{$\begin{array}{l}\text { Internal } \\
\text { Floors }\end{array}$} & $\begin{array}{l}\text { Floor } \\
\text { coating }\end{array}$ & 0.02 & 0.18 & 1100 & 920 & \multirow[b]{2}{*}{0.32} \\
\hline & $\begin{array}{c}\mathrm{L} / \mathrm{W} \\
\text { concrete }\end{array}$ & 0.06 & 0.15 & 500 & 1050 & \\
\hline & $\begin{array}{l}\text { heavy } \\
\text { insulation }\end{array}$ & 0.04 & 0.052 & 92 & 982 & \multirow{4}{*}{0.172} \\
\hline & concrete & 0.2 & 1.7 & 2300 & 880 & \\
\hline \multirow{2}{*}{ Roof } & $\begin{array}{c}\text { Light } \\
\text { insulation }\end{array}$ & 0.2 & 0.036 & 20 & 750 & \\
\hline & concrete & 0.15 & 1.7 & 2300 & 880 & \\
\hline \multirow{2}{*}{$\begin{array}{l}\text { External } \\
\text { Floor }\end{array}$} & $\begin{array}{l}\text { Floor } \\
\text { coating }\end{array}$ & 0.005 & 0.18 & 1100 & 920 & \multirow[t]{2}{*}{2.9} \\
\hline & concrete & 0.25 & 1.7 & 2300 & 880 & \\
\hline \multirow{3}{*}{$\begin{array}{l}\text { Basement } \\
\text { wall } \\
\text { towards } \\
\text { Ground }\end{array}$} & Render & 0.01 & 0.8 & 1800 & 790 & \multirow{2}{*}{3.332} \\
\hline & Concrete & 0.2 & 1.7 & 2300 & 880 & \\
\hline & $\begin{array}{c}\text { Plasterboard } \\
\text { Air in } 30\end{array}$ & 0.064 & 0.4 & 1250 & 840 & \multirow{5}{*}{1.12} \\
\hline \multirow[t]{4}{*}{$\begin{array}{l}\text { Slab on } \\
\text { ground }\end{array}$} & $\begin{array}{l}\mathrm{mm} \\
\text { vert.air } \\
\text { gap }\end{array}$ & 0.3 & 0.17 & 1.2 & 1006 & \\
\hline & $\begin{array}{l}\text { Plasterboard } \\
\text { reinforced }\end{array}$ & 0.02 & 0.4 & 1250 & 840 & \\
\hline & $\begin{array}{l}\text { concrete } \\
\text { screed }\end{array}$ & 0.0155 & 1.55 & 2400 & 840 & \\
\hline & gravel & 0.5 & 0.35 & 1800 & 840 & \\
\hline
\end{tabular}

Table 2. Glass parameters.

\begin{tabular}{ccccccc}
\hline & $\begin{array}{c}\text { Solar Heat } \\
\text { Gain Coef- } \\
\text { ficient } \\
\text { (SHGC) }\end{array}$ & $\begin{array}{c}\text { T, Solar } \\
\text { Transmit- } \\
\text { tance }\end{array}$ & $\begin{array}{c}\text { Tvis, } \\
\text { Visible } \\
\text { Transmit- } \\
\text { tance }\end{array}$ & $\begin{array}{c}\text { Glazing } \\
\text { U-Value } \\
\mathbf{W} / \mathbf{m}^{2} \mathbf{K}\end{array}$ & $\begin{array}{c}\text { Internal } \\
\text { Emissivity }\end{array}$ & $\begin{array}{c}\text { External } \\
\text { Emissivity }\end{array}$ \\
\hline Glass & 0.52 & 0.50 & 0.71 & 0.80 & 0.837 & 0.837 \\
\hline
\end{tabular}




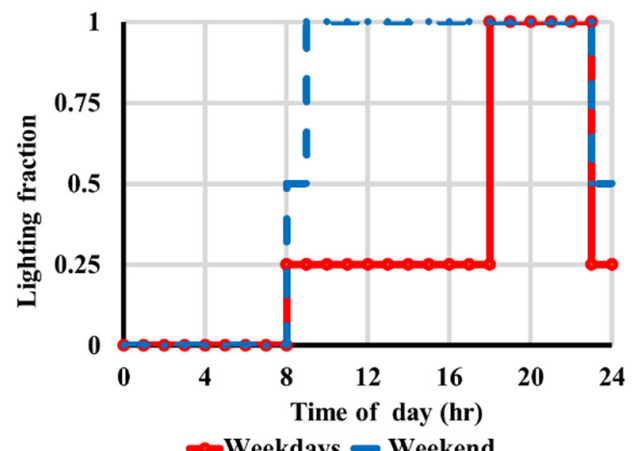

-Weekdavs - Weekend

(a)

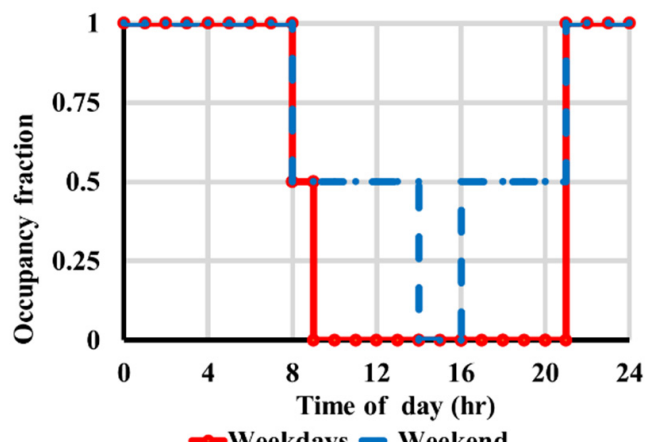

(c)

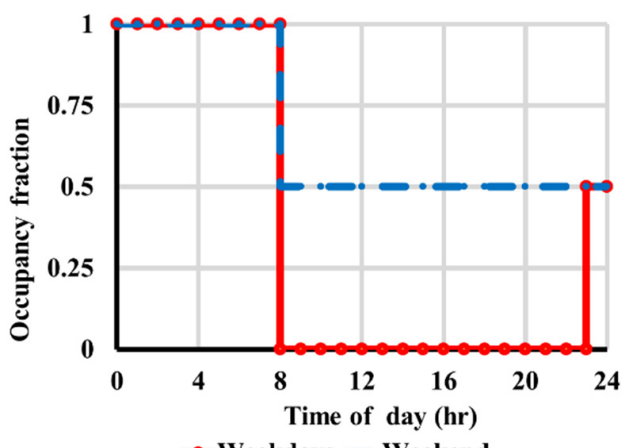

-Weekdavs - Weekend

(e)

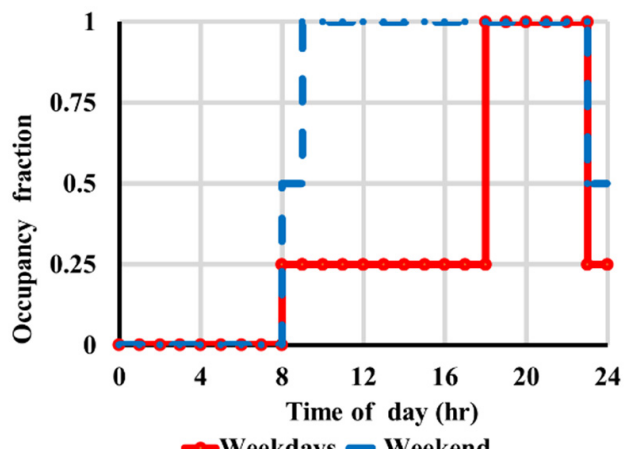

(g)

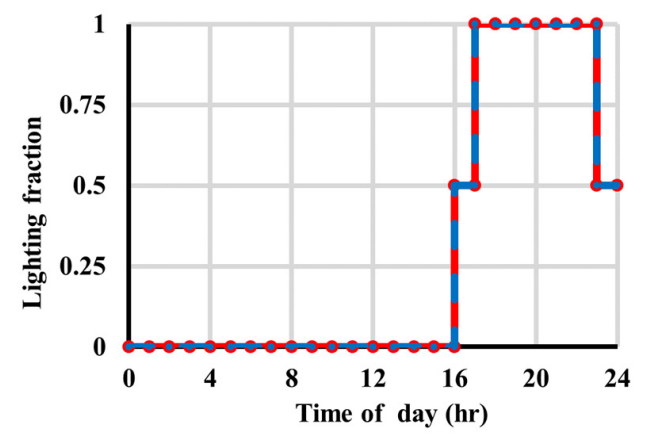

$\infty$ Weekdavs - Weekend

(b)

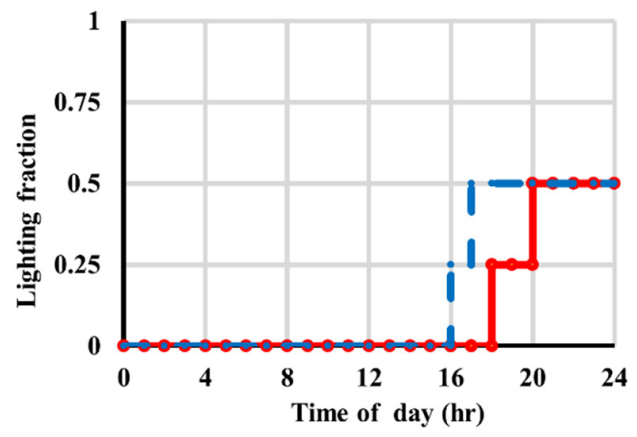

(d)

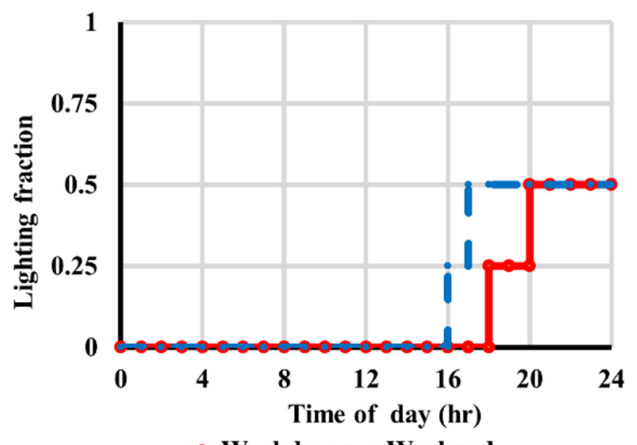

(f)

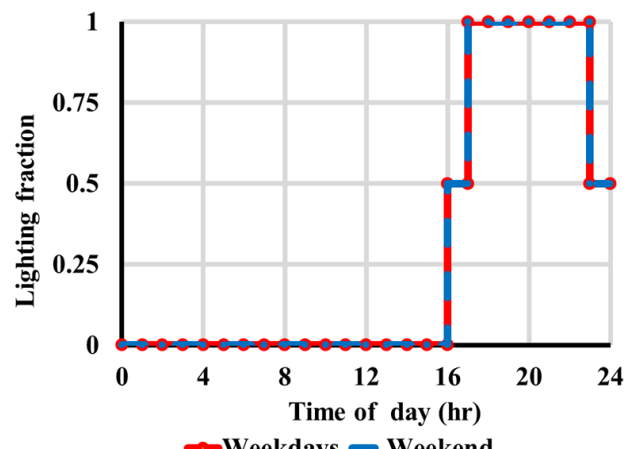

(h)

Figure 2. Cont. 


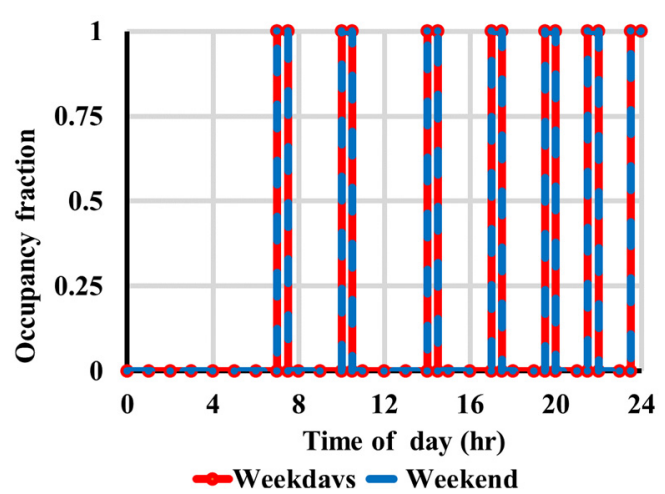

(i)

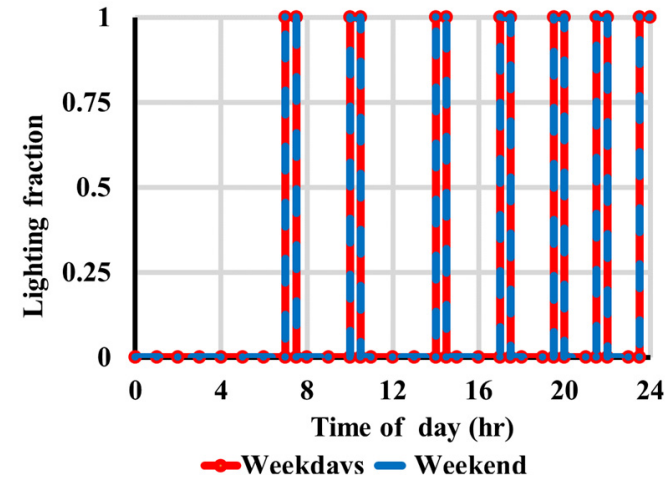

(j)

Figure 2. Occupancy and lighting schedules on weekdays and weekend for different thermal zones $(\mathbf{a}, \mathbf{b})$ living room; $(\mathbf{c}, \mathbf{d})$ bedroom; (e,f) children room; $(\mathbf{g}, \mathbf{h})$ kitchen; and $(\mathbf{i}, \mathbf{j})$ toilet.

Hungary is located in the temperate climatic zone. The average monthly temperate and relative humidity are shown in Figure 3. The highest temperature was observed in August with an average value of 29.2 while December represents the coldest month with an average temperature of $21.9^{\circ} \mathrm{C}$. In this building, the average relative humidity is $32.4 \%$. The heating-cooling temperature was defined between 21 and $25{ }^{\circ} \mathrm{C}$, heating-cooling temperature, and heating-cooling temperature between 20 and $80 \%$.

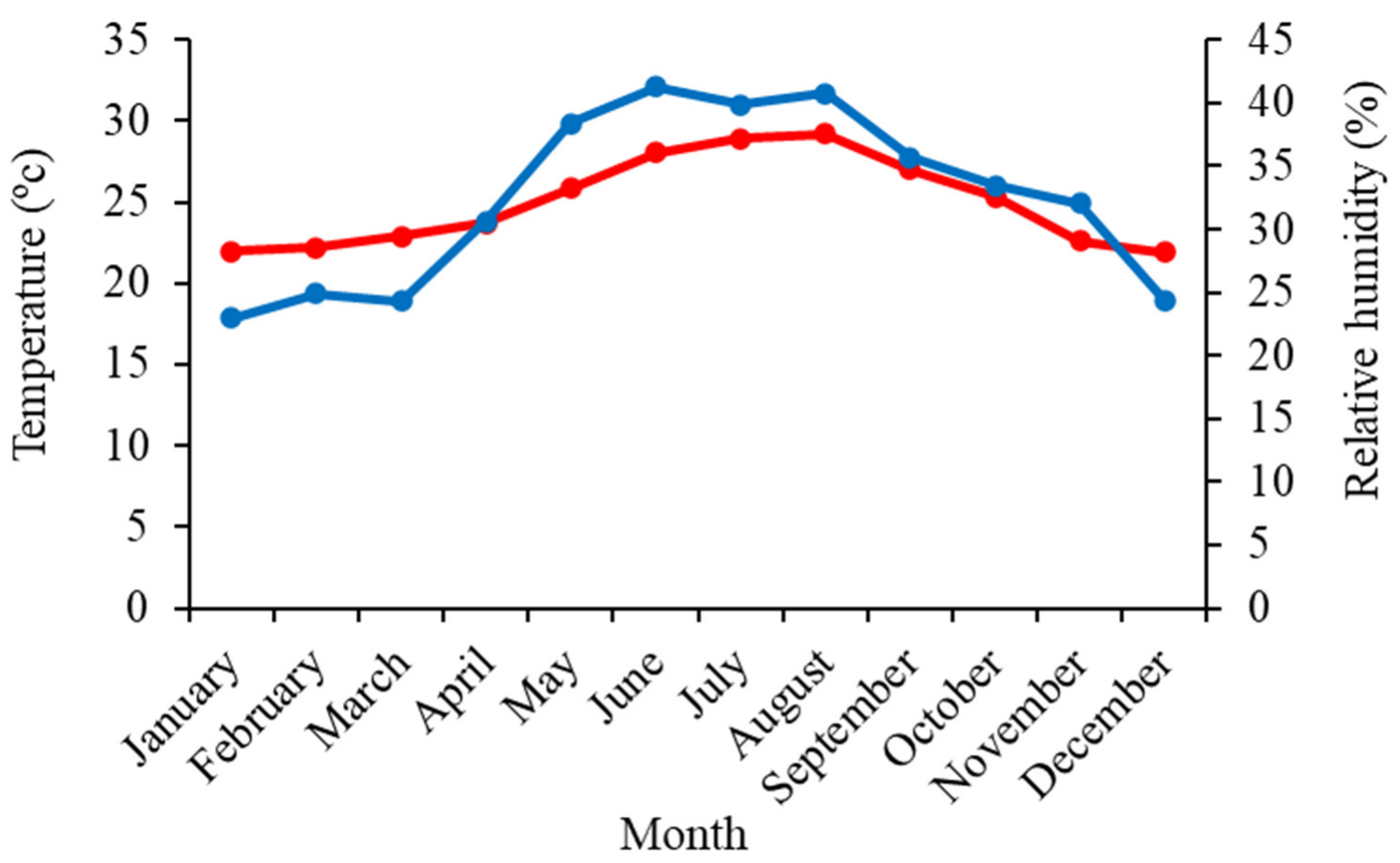

$\rightarrow$ Mean air temperature $\rightarrow$ Relative humidity

Figure 3. Average monthly air temperature and relative humidity. 


\subsection{Sensitivity Analysis}

To gain a better knowledge of the building's performance, sensitivity analysis was used to identify the relationship between independent and dependent factors. Sensitivity analysis is utilized in building design, retrofitting, stock management, and assessing the impact of climate change on structures (see $[26,28,32,34,42-45]$. They can be applied to define the key variables influencing building thermal performance based on both observational studies and energy simulation models. Sensitivity analysis is defined as a measure of the impact of a given input on the output [46]. It can quantitatively examine the impact of each parameter of a building envelope and define important design parameters for reducing energy consumption and improving the thermal environment. In this paper, a sensitivity analysis method was used. Sensitivity analysis is frequently quantified in building research as the difference in simulated results caused by changes in input parameters. It gives designers a reliable tool for quantifying the impact of various design parameters and identifying sources of uncertainty. It has also been applied widely in building energy analysis as it not only prioritizes energy-saving solutions but also analyzes energy-use patterns for energy optimization and model calibration [47-49].

The sensitivity methods utilized in building performance analysis may be classified into two types: global and local sensitivity analysis approaches [48]. Global techniques are increasingly used in research because they consider the consequences of uncertain inputs over the whole input space [50] which allows for a more complete examination of the link between inputs and outputs throughout the whole input space. This, in return, results in more dependable energy-saving solutions. The downsides of utilizing global techniques are that they are more computationally intensive than local sensitivity analyses. Global sensitivity analyses can be further classified into the following approaches: Morris design, screening-based methods [40,51-56], variance-based methods [39,51,56-58], regression methods [26,32,59-69], and meta-modeling approaches [27,33,70]. Local sensitivity analysis techniques, on the other hand, can only investigate the connection between the data points utilized in the analysis without taking into account interactions among inputs [71]. They are mainly concerned with the impacts of uncertain inputs at a point (or base case).

This section describes how different model parameters entered influence variations in model output by using a number of estimators relevant for individual parameters. The effect of a parameter is determined by changing input and analyzing changes in output. It can be applied to determine the extent to which each input parameter contributes to the generation of output variability and to define the most significant parameters. The sensitivity coefficient $\mathrm{Sm}$ of the design parameter $\mathrm{m}$ can be determined as [5,72].

$$
\mathrm{Sm}=\frac{(\Delta \mathrm{X} / \mathrm{Xn})}{(\Delta \mathrm{Ym} / \mathrm{Ym}, \mathrm{n})} \times 100 \%
$$

where $\Delta \mathrm{Ym}$ is the change in the value of input parameter $\mathrm{m}, \Delta \mathrm{Ym}=\mathrm{Ym}-\mathrm{Ym}, \mathrm{n} ; \mathrm{Ym}$ is the value of the input parameter $\mathrm{m} ; \mathrm{Ym}, \mathrm{n}$ is the value of the input parameter $\mathrm{m}$ as a baseline value; $\Delta \mathrm{X}$ is the output variation for the change in the input parameter, $\Delta \mathrm{X}=\mathrm{Xm}$ $-\mathrm{Xn} ; \mathrm{Xm}$ is the output value corresponding to the input value $\mathrm{Ym}$; and $\mathrm{Xn}$ is the output value in the baseline case.

Sensitivity analysis can help to improve the efficiency of the design process and optimize the envelope of a building [40]. The structure of sensitivity analysis is presented in Figure 4. The four basic steps for sensitivity analysis are:

- Specify the input and output variables, as well as the interval and range of each input parameter;

- Assign the baseline design parameters and compute the output of the baseline case;

- Compute the output distribution due to the variations of a given input parameter, and compute the sensitivity coefficient using Equation (1); and

- Evaluate the impact and significance of each design parameter on the output variables. 


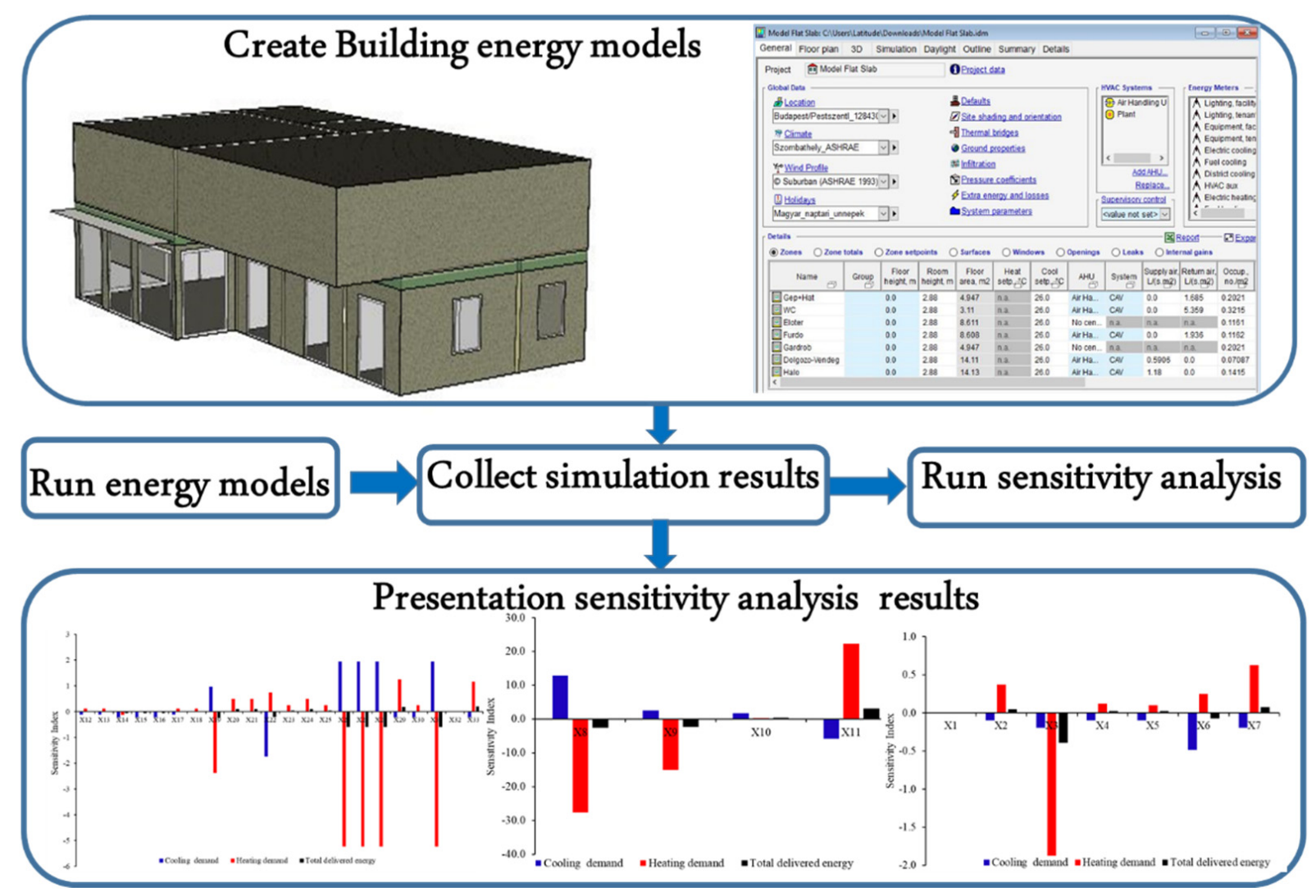

Figure 4. Structure of methodology.

\subsubsection{Input Parameters}

Before conducting sensitivity analysis, it is critical to define which input parameters will be examined. To determine this a literature study [70,73-75] was conducted which allowed information regarding distributions utilized for each input parameter type to be obtained. Such uncertainties influence a total of 33 input parameters. As input parameters, 33 envelope design parameters were chosen (exterior floor type, exterior wall type, interior wall type, glazing type, infiltration rate type, thickness, density, specific heat, and thermal conductivity for basement, exterior floor, interior floor, exterior wall, interior wall, roof, and ground slab). Table 3 presents parameters and parameter ranges used in sensitivity analysis. Different materials for the exterior floor, exterior wall, and interior wall were applied. Density, specific heat, and thermal conductivity for concrete range from 2100 to $2500 \mathrm{~kg} / \mathrm{m}^{3}, 672$ to $1050 \mathrm{~J} / \mathrm{kg} \mathrm{K}$, and 1.07 to $1.7 \mathrm{~W} / \mathrm{mK}$, respectively, while ranges 1500 to $1800 \mathrm{~kg} / \mathrm{m}^{3}, 800$ to $840 \mathrm{~J} / \mathrm{kg} \mathrm{K}$, and 0.58 to $0.73 \mathrm{~W} / \mathrm{mK}$ correspond to the brick. Four different types of glazing were selected. Infiltration flowrate ranged from 0.2 to $2 \mathrm{~m}^{3} / \mathrm{s}$. The thickness range for the building envelope is presented in Table 3.

\subsubsection{Output Variables}

The output variables included the assessment of energy consumption and indoor thermal comfort performance. The delivered of energy for heating and cooling, lighting, equipment, and appliances, and DHW are investigated. $\mathrm{CO}_{2}$ concentrations were assessed as one of the main indices to evaluate thermal comfort. 
Table 3. Parameters and parameter ranges used in sensitivity analysis.

\begin{tabular}{|c|c|c|c|c|c|}
\hline & $\begin{array}{l}\text { Description of } \\
\text { Parameters }\end{array}$ & Name & Range * & Type & Distribution \\
\hline \multirow{7}{*}{$\begin{array}{l}\text { Thickness } \\
\text { (m) }\end{array}$} & Basement & $\mathrm{X} 1$ & $0.21-0.30$ & Continues & Uniform \\
\hline & Exterior floor & $\mathrm{X} 2$ & $0.20-0.30$ & Continues & Uniform \\
\hline & Interior floor & $\mathrm{X} 3$ & $0.15-0.25$ & Continues & Uniform \\
\hline & Exterior wall & $\mathrm{X} 4$ & $0.15-0.25$ & Continues & Uniform \\
\hline & Interior wal & X5 & $0.11-0.20$ & Continues & Uniform \\
\hline & Roof & X6 & $0.20-0.35$ & Continues & Uniform \\
\hline & Ground slab & $\mathrm{X} 7$ & $0.12-0.25$ & Continues & Uniform \\
\hline \multirow{4}{*}{ Material } & Exterior floor & $\mathrm{X} 8$ & $100,101, \ldots, 103$ & Discrete & Uniform \\
\hline & Exterior wall & $\times 9$ & $200,201, \ldots, 205$ & Discrete & Uniform \\
\hline & Interior wall & $\mathrm{X} 10$ & $300,301, \ldots, 303$ & Discrete & Uniform \\
\hline & Glazing type & $\mathrm{X} 11$ & $400,401, \ldots, 404$ & Discrete & Uniform \\
\hline \multirow{7}{*}{$\begin{array}{l}\text { Density } \\
\left(\mathrm{kg} / \mathrm{m}^{3}\right)\end{array}$} & Basement & $\mathrm{X} 12$ & $2100-2500$ & Continues & Uniform \\
\hline & Exterior floor & $\mathrm{X} 13$ & $2100-2500$ & Continues & Uniform \\
\hline & Interior floor & $\mathrm{X} 14$ & $2100-2500$ & Continues & Uniform \\
\hline & Exterior wall & $\mathrm{X} 15$ & $1500-1800$ & Continues & Uniform \\
\hline & Interior wall & $\mathrm{X} 16$ & $1500-1800$ & Continues & Uniform \\
\hline & Roof & $\mathrm{X} 17$ & $2100-2500$ & Continues & Uniform \\
\hline & Ground slab & $\mathrm{X} 18$ & $2100-2500$ & Continues & Uniform \\
\hline \multirow{7}{*}{$\begin{array}{l}\text { Specific heat } \\
((\mathrm{J} / \mathrm{kg} \mathrm{K})\end{array}$} & Basement & X19 & $672-880$ & Continues & Uniform \\
\hline & Exterior floor & $\mathrm{X} 20$ & $672-880$ & Continues & Uniform \\
\hline & Interior floor & $\mathrm{X} 21$ & $672-1050$ & Continues & Uniform \\
\hline & Exterior wall & $\mathrm{X} 22$ & $800-840$ & Continues & Uniform \\
\hline & Interior wall & $\mathrm{X} 23$ & $800-840$ & Continues & Uniform \\
\hline & Roof & $\mathrm{X} 24$ & $672-880$ & Continues & Uniform \\
\hline & Ground slab & $\mathrm{X} 25$ & $672-840$ & Continues & Uniform \\
\hline \multirow{7}{*}{$\begin{array}{c}\text { Thermal } \\
\text { conductivity } \\
(\mathrm{W} / \mathrm{mK})\end{array}$} & Basement & $\mathrm{X} 26$ & $1.07-1.7$ & Continues & Uniform \\
\hline & Exterior floor & $\mathrm{X} 27$ & $1.07-1.7$ & Continues & Uniform \\
\hline & Interior floor & $\mathrm{X} 28$ & $1.07-1.7$ & Continues & Uniform \\
\hline & Exterior wall & X29 & $0.58-0.73$ & Continues & Uniform \\
\hline & Interior wall & $\mathrm{X} 30$ & $0.58-0.73$ & Continues & Uniform \\
\hline & Roof & $\mathrm{X} 31$ & $1.07-1.7$ & Continues & Uniform \\
\hline & Ground slab & $\mathrm{X} 32$ & $1.07-1.7$ & Continues & Uniform \\
\hline $\begin{array}{l}\text { Infiltration } \\
\text { rate }\left(\mathrm{m}^{3} / \mathrm{s}\right)\end{array}$ & Infiltration rate & X33 & $0.2-2.0$ & Continues & Uniform \\
\hline
\end{tabular}

* For discrete parameters, each number in IDA-ICE represents a codified name of a building element (e.g., 101 indicates "Exterior floor-joist floor against").

\section{Results and Discussions}

\subsection{Sensitivity Analysis for the Energy Assessment}

The goal of the research was to address some of the concerns discovered in existing literature analysis and case study into input parameters and evaluate what kind of influence these issues have on energy consumption and thermal comfort. Although the sensitivity analysis results cannot be applied to all structures, the study demonstrates that different input factors have variable effects on the building's thermal performance. As a result, the study reaffirms the necessity for participants to be more strategic in determining where to place their emphasis when collecting field data, conducting tests, and modeling buildings. The input parameters are divided into three groups: thickness change parameters; materials change parameters; density-specific heat and thermal conductivity parameters while other relevant parameters, such as building geometry, occupancy schedules, temperature setpoints, air change rates, and natural ventilation are assumed to be constant. Thus, the generated findings cannot be generalized to all dwellings, which may diminish the likelihood of our findings in different types of dwellings. 
The results demonstrate that only heating and cooling demand varies with the different runs of sensitivity analysis with very little variation in energy demand for illumination, facility, equipment, tenant, and DHW. Figure 5 shows the mean sensitivity coefficient for each change in the thickness parameter for heating demand, cooling demand, and total delivered energy. The sensitivity coefficients of interior floor thickness (X3) represent the highest value of $1.9 \%$ and $0.2 \%$ for cooling and total delivered energy, respectively, while the basement thickness (X1) has the lowest sensitivity coefficient value for cooling, heating, and total energy. The thickness of the interior floor and interior wall also have minimal impact on delivered energy.

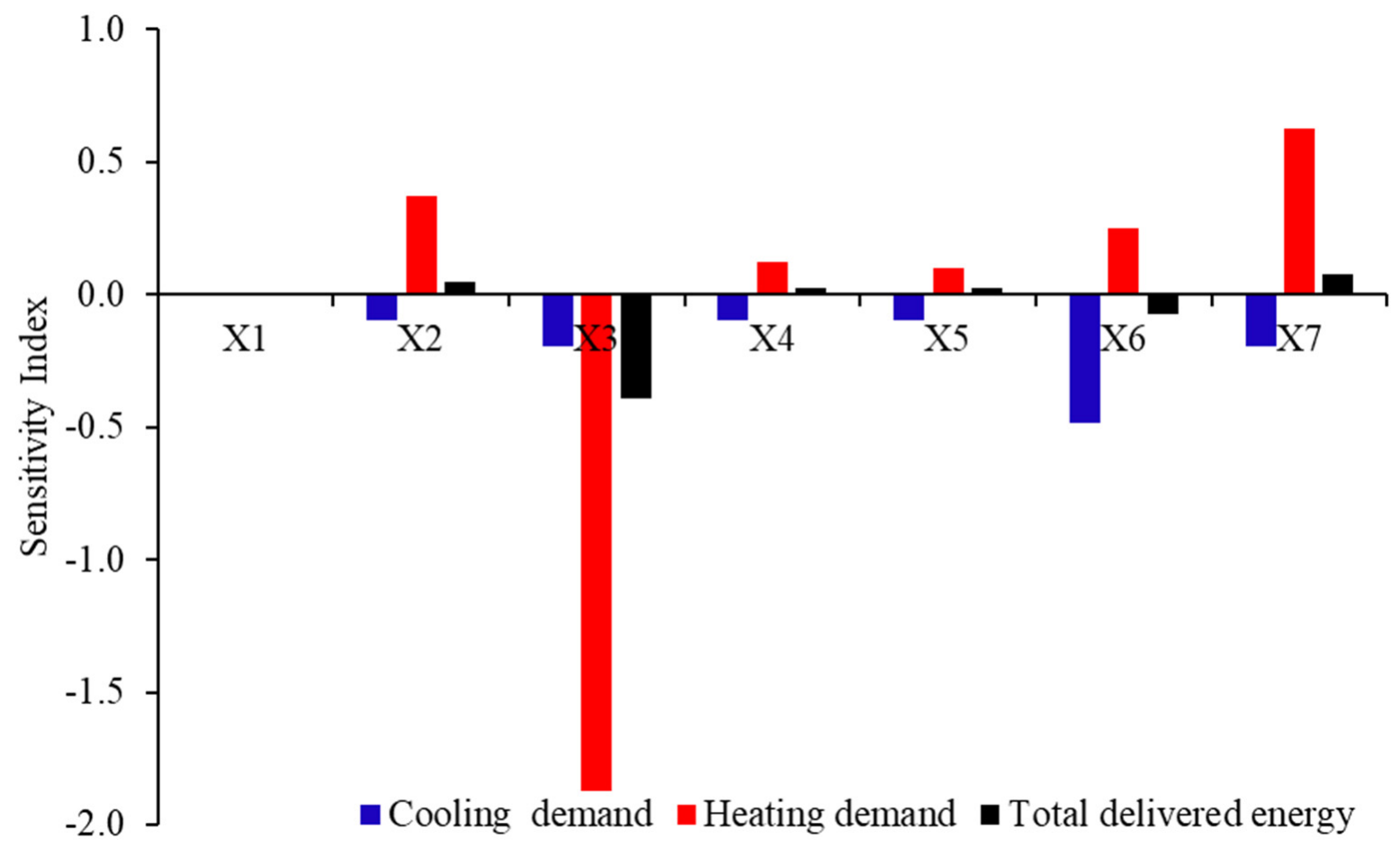

Figure 5. Sensitivity coefficient of thickness change parameters.

Figure 6 presents the mean sensitivity coefficient of material change design parameters. With respect to material change design parameters, the weights of exterior floor material (X8) are $27.7 \%$ and $12.8 \%$ for heating and cooling demand, respectively. The exterior floor material of the roof also plays an important role in delivered energy. The sensitivity coefficient of the glazing type (X11) is $22.3 \%$ and $5.9 \%$, and the sensitivity coefficient of the exterior wall material (X9) is $15.1 \%$ and $2.6 \%$ for heating and cooling demand, respectively. On the other hand, the internal wall materials (X10) have minimal effect on the energy demand for cooling and heating with a sensitivity coefficient of $0.2 \%$ and $1.7 \%$, respectively.

The mean sensitivity coefficient of density, specific heat, thermal conductivity, and the infiltration rate design parameter for heating demand, cooling demand, and total delivered energy are shown in Figure 7. The sensitivity analysis reveals that the density of the basement wall, exterior floor and wall, interior floor and wall, roof, and ground slab, (X12-X18); all have a minimal effect on electric heating demand and cooling demand and total delivered energy. Thermal conductivity of the basement wall, interior floor, exterior floor materials (X26-X28) have the greatest impact on heating and cooling demand with sensitivity coefficients of $5.24 \%, 1.95 \%$, and $0.59 \%$, respectively. The thermal conductivity sensitivity coefficient of the roof (X31) and the exterior wall (X29) are $5.2 \%$ and $1.2 \%$, respectively, for the heating demand. The sensitivity coefficient of the basement specific heat (X19), exterior and interior specific heat (X20-X21) are 2.4\% 
and $0.5 \%$, respectively, while the sensitivity coefficient of the exterior wall specific heat is $1.7 \%$ for cooling demand.

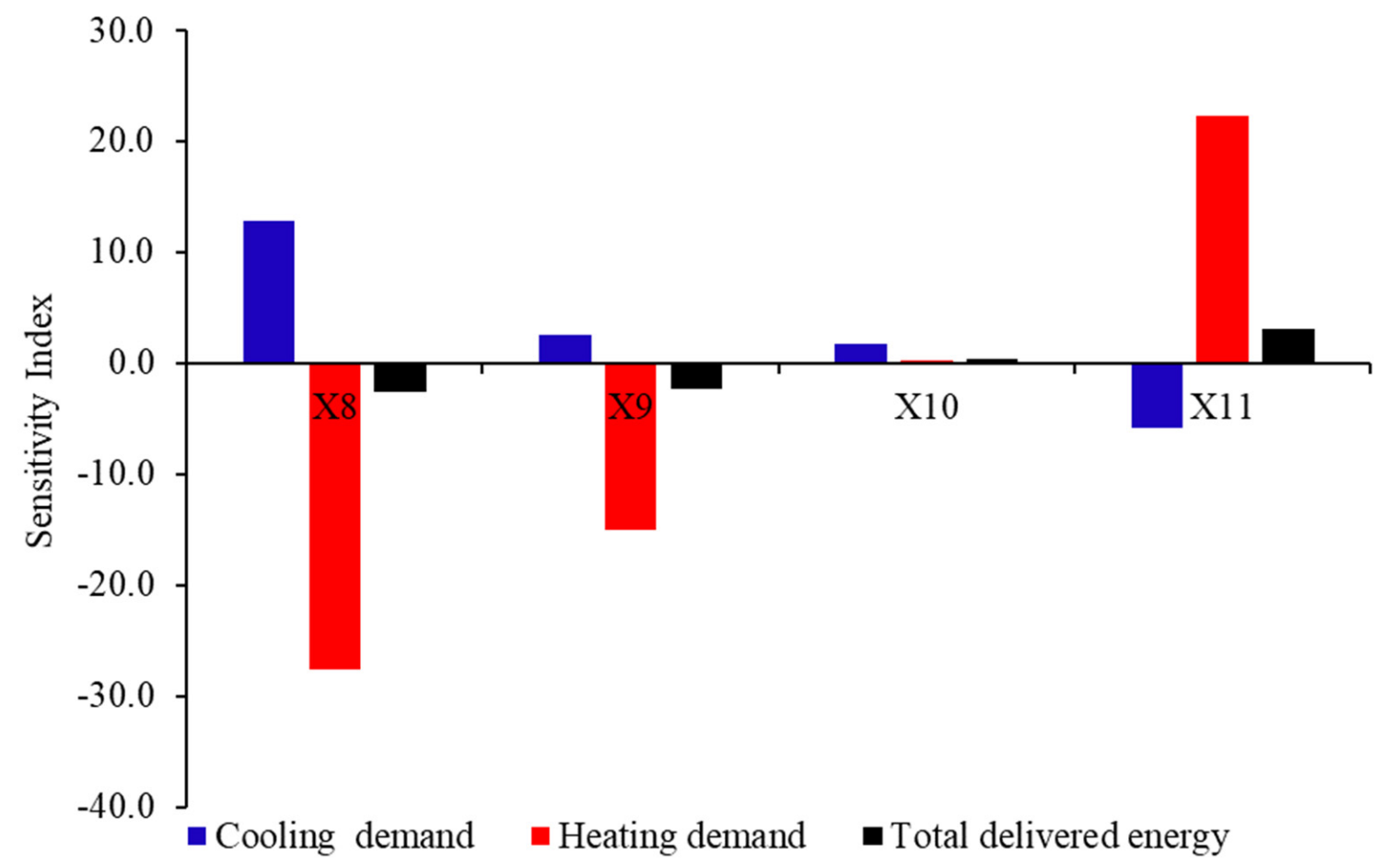

Figure 6. Sensitivity coefficient for different materials.

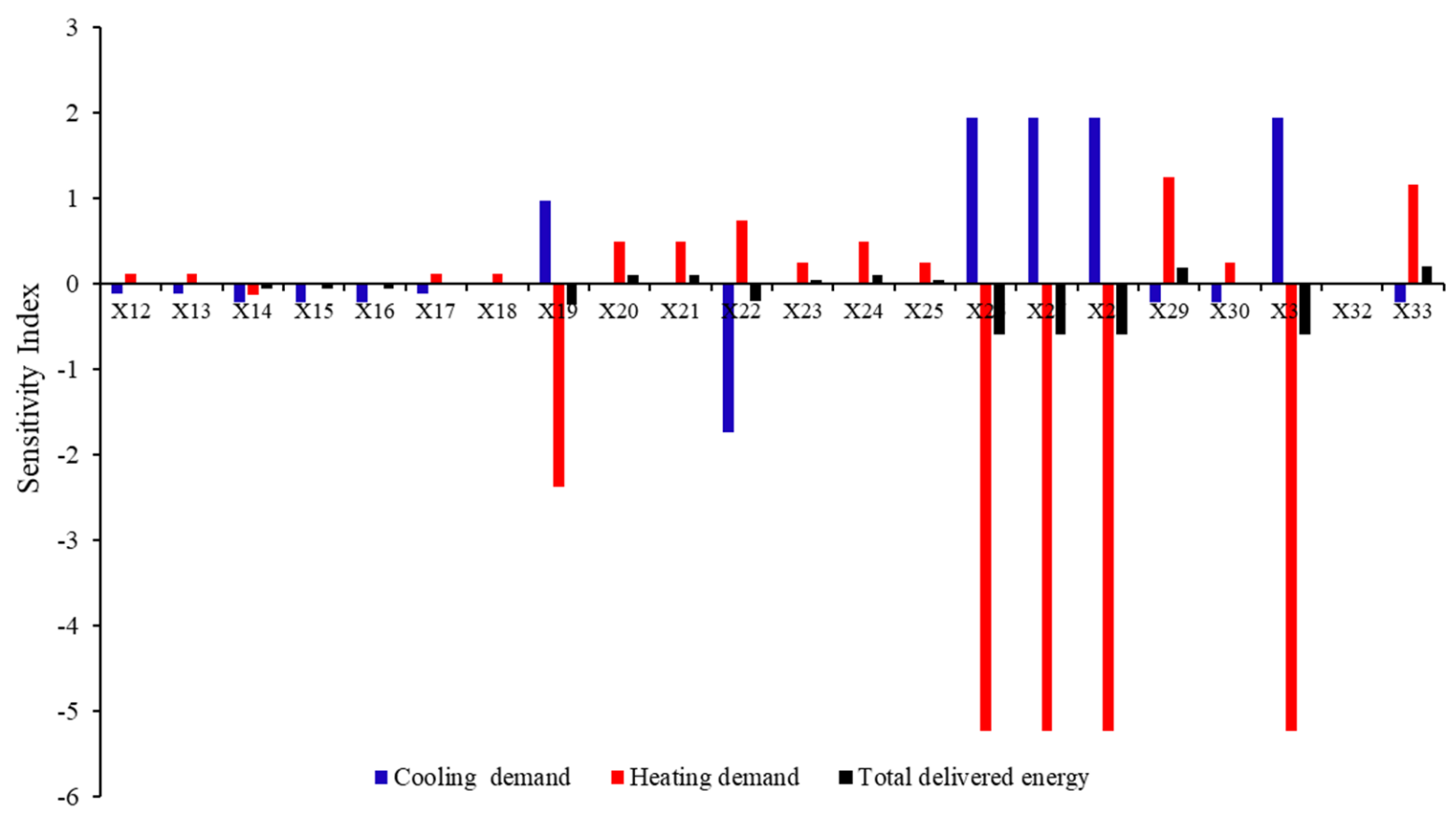

Figure 7. Sensitivity coefficient of density, specific heat, and thermal conductivity parameters.

Figures 5-7 depict that changes to the material parameters have the most obvious effect on total delivered energy. The impact of thermal conductivity parameters is the second most sensitive category, followed by the specific heat design parameters in the third group and thickness change design parameters in the fourth group. Finally, the density of all 
structural materials comes in the least sensitive category. This study provides an overview of which design factors are most important for enhancing the thermal environment of buildings. Given the limited time available for energy modelers to construct energy models, the emphasis should be on ensuring that the inputs having the greatest influence are tailored to properly represent the existing building circumstances.

The findings are especially intriguing since the input factors that had the greatest influence on energy analysis results corresponded to current building information, occupancy schedules, and thermostat settings, which industry observers could easily record during an energy audit. Because these characteristics are generally constant before and after the retrofit, more accurate modeling would be possible. Moreover, the results can assist designers in the early stages of envelope design of newly constructed buildings, as well as envelope rehabilitation of existing buildings.

\subsection{Sensitivity Analysis on Carbon Dioxide $\left(\mathrm{CO}_{2}\right)$ Concentrations}

Carbon dioxide concentration is used as an indication of indoor air quality [76]. The link between indoor air quality and indoor $\mathrm{CO}_{2}$ concentrations stems from the idea that individuals produce bio effluents odors while also creating $\mathrm{CO}_{2}$ [76]. $\mathrm{CO}_{2}$ concentration is also used to classify indoor air quality in European Standard EN 13779 (EN 13779:2007 2019), and the highest value of $\mathrm{CO}_{2}$ concentration is $1500 \mathrm{ppm}$, although it is recommended to keep $\mathrm{CO}_{2}$ concentrations below $1000 \mathrm{ppm}$. In this study, The findings demonstrate that $\mathrm{CO}_{2}$ concentrations were comparatively low with an average value around $651.5 \mathrm{ppm}$ for all scenarios due to more frequent window openings and a higher air exchange rate, resulting in better air quality. Thus, none of the selected design parameters were affected by carbon dioxide levels. Moreover, $\mathrm{CO}_{2}$ concentrations are mainly affected by other variables such as occupancy schedules and air change rates which are assumed to be constant in the current study. Future studies might involve expanding the analysis to include those parameters.

\subsection{Research Limitations and Future Research Opportunities}

The findings of a baseline performance assessment and sensitivity analysis of family residential dwelling are presented in this paper. This study, however, has several limitations. Firstly, the input parameters used for this investigation are constrained to the envelope components, while other variables are assumed to be constant. Other relevant parameters such as building geometry, occupancy schedules, temperature setpoints, and air change rates are not considered in this study. Since this paper presents a specific dwelling with specific assumptions, it is crucial to remember that the specific sensitivities identified by the study are not absolute and cannot be generalized to all dwellings; however, the critical evaluation to examine the underlying functions behind the design recommendations and performance responses to improve building behavior can be applied to a wide range of projects. Secondly, because existing information about building factors and their bounds are still restricted, the number of input parameters and their ranges must be expanded, as with many other forms of SA research. Future studies might involve expanding the analysis to include those parameters or determining whether the same parameters for the same building would have a different degree of sensitivity if an energy modeling program other than IDA-ICE was used. As a future study recommendation, the same procedure might be applied for data from other regions to determine if the relevant input parameters change regionally. Finally, the analysis exclusively addresses Budapest's climate circumstances, using a single climate file, and cannot predict the impacts of climate change in the upcoming years. As a result, future studies should consider the consequences of climate change to provide more realistic results.

\section{Conclusions}

Sensitivity analysis is typically performed in conjunction with energy simulations to better understand building performance and minimize consumption. The quality of 
their outputs is mostly determined by the thermal models and input data. It is challenging to obtain reliable data regarding the attributes and operational status of buildings. As a result, simulation inputs are influenced by uncertainties, which can have a major impact on outcomes and must be considered.

Uncertainty analysis considers uncertainties caused by intrinsic model simplifications and a lack of knowledge about input data. The paper discussed the possible use of sensitivity analysis in the field of buildings' thermal performance analysis and demonstrated its practical application via a case study. The sensitivity coefficient of 33 envelope design parameters for delivered energy and thermal comfort were calculated and compared for buildings in Budapest, Hungary. The most critical design parameters were identified for the analyzed building. The results showed that the material of the exterior floor had the most significant impact on the delivered energy of the building. The parameter's influence in terms of weights were $27.7 \%, 12.8 \%$, and $2.6 \%$ for heating demand, cooling demand, and total delivered energy, respectively. The second most influencing factors were the thermal conductivity parameters. The impact of the density of all structural elements and the thickness of the basement floor, exterior floor, interior floor, and wall had the least impact on total delivered energy.

All envelope design parameters had minimal impact on carbon concentrations. This study provides an overview of which design factors are most important for enhancing the thermal environment of buildings. Future study will concentrate on expanding these ideas to further advance energy modeling process standards. These findings were interesting since not only did these misrepresented inputs have the greatest influence of those examined, but much of the input parameter data would be very straightforward to collect through a site visit, tests, and interviews with the building inhabitants. Moreover, they can assist designers in the early stages of envelope design for newly constructed buildings, as well as envelope rehabilitation of existing buildings.

Author Contributions: Conceptualization, S.E. and Z.O.; methodology, S.E.; software, S.E.; validation, S.E. and Z.O.; formal analysis, S.E.; investigation, S.E.; resources, S.E. and Z.O.; data curation, S.E.; writing—original draft preparation S.E.; writing—review and editing Z.O.; visualization S.E.; supervision Z.O.; project administration, Z.O. funding acquisition, Z.O. All authors have read and agreed to the published version of the manuscript.

Funding: This research was funded by the Biomedical Engineering Project of the Thematic Excellence Programme 2019 (TUDFO/51757-1/2019-ITM).

Institutional Review Board Statement: Not applicable.

Informed Consent Statement: Not applicable.

Data Availability Statement: The data presented in this study are available on request from the corresponding author. The data are not publicly available due to privacy issues.

Acknowledgments: The research project is conducted at the University of Pécs, Hungary, within the framework of the Biomedical Engineering Project of the Thematic Excellence Programme 2019 (TUDFO/51757-1/2019-ITM). The first author would like to thank the Egyptian Ministry of Higher Education (MoHE) and Tempus Public Foundation for providing her the Stipendium Hungaricum Scholarship. Also, we appreciate Mahmoud Khaled for his technical help in model development. Further we appreciatethe János Szentágoghai Research Centre, University of Pécs, Energia Design Research Group, led by István Kistelegd.

Conflicts of Interest: The authors declare no conflict of interest. 


\section{Appendix A}

Table A1. Thermal Zones properties in the investigated Building.

\begin{tabular}{cccccc}
\hline $\begin{array}{c}\text { Thermal } \\
\text { Zone }\end{array}$ & $\begin{array}{c}\text { Area } \\
\left(\mathbf{m}^{\mathbf{2}}\right)\end{array}$ & $\begin{array}{c}\text { Volume } \\
\left(\mathbf{m}^{\mathbf{3}} \mathbf{)}\right.\end{array}$ & $\begin{array}{c}\text { Glazing } \\
\text { Area } \\
\mathbf{( m}^{\mathbf{2}}\end{array}$ & $\begin{array}{c}\text { Glazing to } \\
\text { Floor Area } \\
\text { Ratio }\end{array}$ & $\begin{array}{c}\text { Thermal } \\
\text { Bridges } \\
\mathbf{( W / K )}\end{array}$ \\
\hline Zone 1 & 36.8 & 105.8 & 3.4 & 0.1 & 13.5 \\
Zone 2 & 2.8 & 8.2 & 1.1 & 0.4 & 1.5 \\
Zone 3 & 1.8 & 5.1 & 0.0 & 0.0 & 0.0 \\
Zone 4 & 4.9 & 14.2 & 1.1 & 0.2 & 1.5 \\
Zone 5 & 3.1 & 9.0 & 0.5 & 0.2 & 1.0 \\
Zone 6 & 8.6 & 24.8 & 7.0 & 0.8 & 3.1 \\
Zone 7 & 8.6 & 24.8 & 1.1 & 0.1 & 2.2 \\
Zone 8 & 4.9 & 14.2 & 1.1 & 0.2 & 1.5 \\
Zone 9 & 14.1 & 40.6 & 1.8 & 0.1 & 4.6 \\
Zone 10 & 58.0 & 167.1 & 33.4 & 0.6 & 15.3 \\
Zone 11 & 7.1 & 20.4 & 0.0 & 0.0 & 0.1 \\
Zone 12 & 10.4 & 30.1 & 3.6 & 0.3 & 3.1 \\
Zone 13 & 12.7 & 36.5 & 3.6 & 0.3 & 3.3 \\
Zone 14 & 14.1 & 40.7 & 5.4 & 0.4 & 5.9 \\
Zone 15 & 14.1 & 36.7 & 0.0 & 0.0 & 0.1 \\
Zone 16 & 8.6 & 22.4 & 0.0 & 0.0 & 0.2 \\
Zone 17 & 58.0 & 150.8 & 19.0 & 0.3 & 3.5 \\
Zone 18 & 102.4 & 266.2 & 0.0 & 0.0 & 8.2 \\
\hline
\end{tabular}

\section{References}

1. Garber, R. Optimisation stories: The impact of building information modelling on contemporary design practice. Archit. Eng. 2009, 79, 6-13. [CrossRef]

2. Katona, Á.L.; Xuan, H.; Elhadad, S.; Kistelegdi, I.; Háber, I. High-Resolution CFD and In-Situ Monitoring Based Validation of an Industrial Passive Air Conduction System (PACS). Energies 2020, 13, 3157. [CrossRef]

3. Elhadad, S.; Rais, M.; Boumerzoug, A.; Baranyai, B. Assessing the impact of local climate on the building energy design: Case study Algeria-Egypt in hot and dry regions. In Proceedings of the International Conference, Istanbul, Turkey, 20-21 November 2019; pp. 21-24.

4. Hughes, M.; Palmer, J.; Cheng, V.; Shipworth, D. Global sensitivity analysis of England's housing energy model. J. Build. Perform. Simul. 2015, 8, 283-294. [CrossRef]

5. Meng, X.; Wei, B.; Zhai, Y. Sensitivity Analysis of Envelope Design Parameters of Industrial Buildings with Natural Ventilation. Sustainability 2020, 12, 10288. [CrossRef]

6. Hama Radha, C.A.; Elhadad, S.; Kistelegdi, I. Integrated Strategies for Sustainable Urban Renewal in Hot and Dry Climate. In New Metropolitan Perspectives. NMP 2020. Smart Innovation, Systems and Technologies; Bevilacqua, C., Calabrò, F., Della Spina, L., Eds.; Springer: Cham, Switzerland, 2020; Volume 178. [CrossRef]

7. Al-Khawaja, M. Determination and selecting the optimum thickness of insulation for buildings in hot countries by accounting for solar radiation. Appl. Energy 2004, 24, 2601-2610. [CrossRef]

8. Ucar, A. Thermoeconomic analysis method for optimization of insulation thickness for the four dierent climatic regions of Turkey. Energy 2010, 35, 1854-1864. [CrossRef]

9. Huang, J.; Lv, H.; Gao, T.; Feng, W.; Chen, Y.; Zhou, T. Thermal properties optimization of envelope in energy-saving renovation of existing public buildings. Energy Build. 2014, 75, 504-510. [CrossRef]

10. Messaouda, R.; Elhadad, S.; Boumerzoug, A. Optimum window position in the building façade for high day-light performance: Empirical study in hot and dry climate. Pollack Period. 2020, 15, 211-220. [CrossRef]

11. Elhadad, S.; Baranyai, B.; Gyergyák, J.; Kistelegdi, I.; Salem, A. Passive design strategies for residential buildings in a hot desert climate in upper Egypt. In Proceedings of the Multidisciplinary Scientific GeoConference SGEM 2019, Albena, Bulgaria, 28 June-7 July 2019; Volume 19, pp. 495-502.

12. Lomas, K.J.; Eppel, H. Sensitivity analysis techniques for building thermal simulation programs. Energy Build. 1992, 19, 21-44. [CrossRef]

13. Fuerbringer, J.M. Sensitivity of Models and Measurements in the Airflow in Buildings with the Aid of Experimental Plans; Ecole Polytechnique Federale de Lausanne: Lausanne, Switzerland, 1994.

14. Macdonald, I.A. Quantifying the Effects of Uncertainty in Building Simulation. Ph.D. Thesis, University of Strathclyde, Glasgow, Scotland, 2002. 
15. De Wit, M.S. Identification of the important parameters in thermal building simulation models. J. Stat. Comput. Simul. 1997, 57, 305-320. [CrossRef]

16. Elhadad, S.; Radha, C.H.; Kistelegdi, I.; Baranyai, B.; Gyergyák, J. Model Simplification on Energy and Comfort Simulation Analysis for Residential Building Design in Hot and Arid Climate. Energies 2020, 13, 1876. [CrossRef]

17. Litko, J.R. Sensitivity analysis for robust parameter design experiments. In Proceedings of the 37th Conference on Winter simulation, Winter Simulation Conference, Orlando, FL, USA; 2005; pp. 2020-2025.

18. Lewandowska, A.; Foltynowicz, Z.; Podlesny, A. Comparative lca of industrial objects. Part 1. lca data quality assurancesensitivity analysis and pedigree matrix. Int. J. Life Cycle Assess 2004, 9, 86-89. [CrossRef]

19. Hopfe, C.J.; Hensen, J.; Plokker, W. Introducing uncertainty and sensitivity analysis in non-modifiable building performance software. In Proceedings of the 1st IBPSA Germany-Austrian Conference (BauSIM 2006), Munich, Germany, 9-11 October 2006.

20. Hopfe, C.J.; Hensen, J.; Plokker, W. Uncertainty and sensitivity analysis for detailed design support. In Proceedings of the 10th IBPSA Building Simulation Conference, Tsinghua University, Beijing, China, 3-6 September 2007; Volume 3, pp. 1799-1804.

21. Hopfe, C.J.; Hensen, J.L.M.; Plokker, W.; Wijsman, A.J.T.M. Model uncertainty and sensitivity analysis for thermal comfort prediction. In Proceedings of the 12th Symposium for Building Physics, Dresden, Germany, 29-31 March 2007 ; pp. 103-112.

22. Hopfe, C.J. Uncertainty and sensitivity analysis in building performance simulation for decision support and design optimization. Ph.D. Thesis, Technische Universiteit Eindhoven, Eindhoven, The Netherlands, 2009.

23. Gokhale, S.S. Model-based performance analysis using block coverage measurements. J. Syst. Softw 2009, 82, 121-130. [CrossRef]

24. Beck, J.; Arnold, K. Parameter Estimation in Engineering and Science; John Wiley \& Sons: New York, NY, USA, 1977.

25. Hygh, J.S.; DeCarolis, J.F.; Hill, D.B.; Ranjithan, S.R. Multivariate regression as an energy assessment tool in early building design. Build Environ. 2012, 57, 165-175. [CrossRef]

26. Hopfe, C.J.; Hensen, J.L.M. Uncertainty analysis in building performance simulation for design support. Energy Build. 2011, 43, 2798-2805. [CrossRef]

27. Westphal, F.S.; Lamberts, R. Building simulation calibration using sensitivity analysis. In Proceedings of the 9th International Building Performance Simulation Association Conference, Montreal, Canada, 15-18 August 2005; pp. 1331-1338.

28. Sun, J.; Reddy, T.A. Calibration of Building Energy Simulation Programs Using the Analytic Optimization Approach (RP-1051). HVACER Res. 2006, 12, 177-196.

29. Gustafsson, S.-I. Sensitivity analysis of building energy retrofits. Appl. Energy 1998, 61, 13-23. [CrossRef]

30. Lam, J.C.; Wan, K.K.W.; Yang, L. Sensitivity analysis and energy conservation measures implications. Energy Convers. Manag 2008, 49, 3170-3177. [CrossRef]

31. Tian, W.; Choudhary, R.A. probabilistic energy model for non-domestic building sectors applied to analysis of school buildings in greater London. Energy Build. 2012, 54, 1-11. [CrossRef]

32. Moran, F.; Natarajan, S.; Nikolopoulou, M. Developing a database of energy use for historic dwellings in Bath, UK. Energy Build. 2012, 55, 218-226. [CrossRef]

33. Tian, W.; de Wilde, P. Uncertainty and sensitivity analysis of building performance using probabilistic climate projections: A UK case study. Autom. Constr. 2011, 20, 1096-1109. [CrossRef]

34. de Wilde, P.; Tian, W. Preliminary application of a methodology for risk assessment of thermal failures in buildings subject to climate change. In Proceedings of the 11th International Building Performance Simulation Association Conference, Glasgow, Scotland, 27-30 July 2009; pp. 2077-2084.

35. Goffart, J.; Rabouille, M.; Mendes, N. Uncertainty and sensitivity analysis applied to hygrothermal simulation of a brick building in a hot and humid climate. J. Build. Perform. Simul 2017, 10, 37-57. [CrossRef]

36. Yu, J.; Tian, L.; Yang, C.; Xu, X.; Wang, J. Sensitivity analysis of energy performance for high-rise residential envelope in hot summer and cold winter zone of China. Energy Build. 2013, 64, 264-274. [CrossRef]

37. Eisenhower, B.; O’Neill, Z.; Fonoberov, V.A.; Mezić, I. Uncertainty and sensitivity decomposition of building energy models. J. Build. Perform. Simul 2012, 5, 171-184. [CrossRef]

38. Spitz, C.; Mora, L.; Wurtz, E.; Jay, A. Practical application of uncertainty analysis and sensitivity analysis on an experimental house. Energy Build. 2012, 55, 459-470. [CrossRef]

39. Mechri, H.E.; Capozzoli, A.; Corrado, V. USE of the ANOVA approach for sensitive building energy design. Appl. Energy 2010, 87, 3073-3083. [CrossRef]

40. Heiselberg, P.; Brohus, H.; Hesselholt, A.; Rasmussen, H.; Seinre, E.; Thomas, S. Application of sensitivity analysis in design of sustainable buildings. Renew. Energy 2009, 34, 2030-2036. [CrossRef]

41. Morris, M.D. Factorial sampling plans for preliminary computational experiments. Technometrics 1991, 33, 161-174. [CrossRef]

42. Heo, Y.; Augenbroe, G.; Graziano, D.; Muehleisen, R.T.; Guzowski, L. Scalable methodology for large scale building energy improvement: Relevance of calibration in model-based retrofit analysis. Build Environ 2015, 87, 342-350. [CrossRef]

43. Song, J.; Wei, L.; Sun, Y.; Tian, W. Implementation of Meta-modelling for Sensitivity Analysis in Building Energy Analysis. In Proceedings of the eSim 2014 Canada's Building Simulation Conference, Ottawa, Canada, 7-10 May 2014.

44. Elhadad, S.; Baranyai, B.; Gyergyák, J. The impact of building orientation on energy performance: A case study in new Minia, Egypt. Pollack Period. 2018, 13, 31-40. [CrossRef] 
45. Attia, S.; Gratia, E.; De Herde, A.; Hensen, J.L.M. Simulation-based decision support tool for early stages of zero-energy building design. Energy Build. 2012, 39, 2-15.

46. Saltelli, A.; Tarantola, S.; Campolongo, F.; Ratto, M. Sensitivity Analysis in Practice; John Wiley \& Sons: Chichester, UK, 2004.

47. Tian, W.; Song, J.; Li, Z.; de Wilde, P. Bootstrap techniques for sensitivity analysis and model selection in building thermal performance analysis. Appl. Energy 2014, 135, 320-328. [CrossRef]

48. Tian, W. A review of sensitivity analysis methods in building energy analysis. Renew. Sustain. Energy Rev. 2013, 20, 411-419. [CrossRef]

49. Tian, W.; Yang, S.; Li, Z.; Wei, S.; Pan, W.; Liu, Y. Identifying informative energy data in Bayesian calibration of building energy models. Energy Build. 2016, 119, 363-376. [CrossRef]

50. Mara, T.; Tarantola, S. Application of global sensitivity analysis of model output to building thermal simulations. Build. Simul. 2008, 1, 290-302. [CrossRef]

51. Sanchez, D.G.; Lacarrière, B.; Musy, M.; Bourges, B. Application of sensitivity analysis in building energy simulations: Combining first- and second-order elementary effects methods. Energy Build. 2014, 68, 741-750. [CrossRef]

52. Heo, Y.; Choudhary, R.; Augenbroe, G.A. Calibration of building energy models for retrofit analysis under uncertainty. Energy Build. 2012, 47, 550-560. [CrossRef]

53. Corrado, V.; Mechri, H.E. Uncertainty and sensitivity analysis for building energy rating. J. Build. Phys. 2009, 33, 125-156. [CrossRef]

54. de Wit, S.; Augenbroe, G. Analysis of uncertainty in building design evaluations and its implications. Energy Build. 2002, 34, 951-958. [CrossRef]

55. Moon, H.J. Uncertainty analysis in mould spore transportation and its application in an existing building. Indoor Built Environ. 2010, 19, 355-365. [CrossRef]

56. Hyun, S.; Park, C.; Augenbroe, G. Analysis of uncertainty in natural ventilation predictions of high-rise apartment buildings. Build. Serv. Eng. Res. Technol. 2008, 29, 311-326. [CrossRef]

57. Shen, H.; Tzempelikos, A. Sensitivity analysis on daylighting and energy performance of perimeter offices with automated shading. Build. Environ. 2013, 59, 303-314. [CrossRef]

58. Flores, R.R.; Bertagnolio, S.; Lemort, V. Global Sensitivity Analysis applied to Total Energy Use in Buildings. In Proceedings of the International High Performance Buildings Conference, Purdue, France, 16-19 July 2012; p. 3484.

59. de Wilde, P.; Tian, W. Identification of key factors for uncertainty in the prediction of the thermal performance of an office building under climate change. Build. Simul. 2009, 2, 157-174. [CrossRef]

60. Yildiz, Y.; Korkmaz, K.; Göksal Özbalta, T.; Arsan, D.Z. An approach for developing sensitive design parameter guidelines to reduce the energy requirements of low-rise apartment buildings. Appl. Energy 2012, 93, 337-347. [CrossRef]

61. Domínguez-Muñoz, F.; Cejudo-López, J.M.; Carrillo-Andrés, A. Uncertainty in peak cooling load calculations. Energy Build. 2010, 42, 1010-1018. [CrossRef]

62. Breesch, H.; Janssens, A. Performance evaluation of passive cooling in office buildings based on uncertainty and sensitivity analysis. Solar Energy. 2010, 84, 1453-1467. [CrossRef]

63. Struck, C.; Hensen, J.; Kotek, P. On the application of uncertainty and sensitivity analysis with abstract building performance simulation tools. J. Build. Phys. 2009, 33, 5-27. [CrossRef]

64. Ballarini, I.; Corrado, V. Analysis of the building energy balance to investigate the effect of thermal insulation in summer conditions. Energy Build. 2012, 52, 168-180. [CrossRef]

65. Tian, W.; de Wilde, P. Sampling-based sensitivity analysis of thermal performance in domestic buildings under climate change. In Proceedings of the EG-ICE (European Group for Intelligient Computing in Engineering), Enschede, The Netherlands, 6-8 July 2011.

66. Wright, J.A.; Wang, M.; Brownlee, A.E.I.; Buswell, R.A. Variable convergence in evolutionary optimization and its relationship to sensitivity analysis. In Proceedings of the First Building Simulation and Optimization Conference, Loughborough, UK, 10-11 September 2012.

67. Brohus, H.; Heiselberg, P.; Simonsen, A.; Srrrensen, K.C. Uncertainty of Energy Consumption assessment of domestic buildings. In Proceedings of the 11th International Building Performance Simulation Association Conference, Glasgow, Scotland, 27-30 July 2009; pp. 1022-1029.

68. Zhao, F. Agent-based modeling of commercial building stocks for energy policy and demand response analysis. Ph.D. Thesis, Georgia Institute of Technology, Atlanta, GA, USA, 2012.

69. Zhao, J.; Xin, Y.; Tong, D. Energy consumption quota of public buildings based on statistical analysis. Energy Policy. 2012, 43, 362-370. [CrossRef]

70. de Wilde, P.; Tian, W. Predicting the performance of an office under climate change: A study of metrics, sensitivity and zonal resolution. Energy Build. 2010, 42, 1674-1684. [CrossRef]

71. Saltelli, A.; Ratto, M.; Andres, T.; Campolongo, F.; Cariboni, J.; Gatelli, D.; Saisana, M.; Tarantola, S. Global sensitivity analysis: The primer, Wiley-Interscience. John Wiley \& Sons Ltd.: West Sussex, UK, 2008.

72. Chow, W.K.; Chan, K.T. Parameterization study of the overall thermal-transfer value equation for buildings. Appl. Energy 1995, 50, 247-268. [CrossRef] 
73. Macdonald, I.A.; Strachan, P. Practical application of uncertainty analysis. Energy Build. 2001, 33, 219-227. [CrossRef]

74. Brohus, H.; Frier, C.; Heiselberg, P.; Haghighat, F. Quantification of uncertainty in predicting building energy consumption: A stochastic approach. Energy Build. 2012, 55, 127-140. [CrossRef]

75. Reddy, T.A.; Maor, I.; Jian, S.; Panjapornporn, C. Procedures for Reconciling Computer-Calculated Results with Measured Energy Data; Technical Report; American Society of Heating, Refrigerating and Air-Conditioning.Engineers: Atlanta, GA, USA, 2006.

76. Batog, P.; Badura, M. Dynamic of Changes in Carbon Dioxide Concentration in Bedrooms. Procedia Eng. 2013, 57, 175-182. [CrossRef] 